\title{
Effects of Demographic Factors on Customers' Mobile Banking Services Adoption in Nigeria
}

\author{
Owolabi Justine Abayomi
}

Alabi Charles Olabode

Md Amjad Hossain Reyad

Emmanuel Tetteh Teye

University of Science and Technology of China

School of Public Affairs

Department of Public Administration

China

\author{
Md Nazmul Haq \\ Comilla University \\ Department of Public Administration \\ Bangladesh \\ Elijah Takyi Mensah \\ Zhejiang Normal University, \\ College of Economics and Management \\ PR China
}

\begin{abstract}
Demographically, the study examines the factors that affect customers to adopt mobile banking services in Benin City. The study specially investigated age, occupation, educational level, gender and income of customers as powerful variables that affects the adoption of mobile banking services by customers in Benin City. The study population consists of all commercial bank individual customers in Benin City. The simple random sampling was employed in order to determine the sample size of six hundred from the entire population. In this study, questionnaire was used to collect the required information from the six hundred bank customers that were sampled. Information collected from the respondents were collected from the respondents were rigorously analyzed with descriptive and inferential statistics. The study showed that demographic factors such as age gender, income level, occupational level, except educational status do influence the adoption of mobile banking services in Benin City.
\end{abstract}

Keywords: Demographic Factors: Adoption: Mobile banking Services.

\section{Introduction}

Mobile banking services is among the recent notable e-banking platform that impact on daily life activities (Safeena, Date, Kammani, \& Hundewale, 2012). Mobile banking services are banking services offered to customers through mobile networks allowing them to personally access bank accounts and perform financial transactions from anywhere anytime using mobile phones (Luarn \& Lin, 2015). It is more convenient, flexible and timely in accessing financial services when compared to other e-banking platforms like Point of Sales, Automated Teller Machines and Computer Banking Software (Agwu \& Carter, 2014). This is because most consumers always go along with their mobile phones which could help them to facilitate quick and easy performance of financial services from anywhere unlike POS and ATMs. In addition to this, mobile banking services have been found to be relatively safer than other e-platforms because they use a higher layered security system (Mukhlis, 2014). These major attributes of mobile banking services coupled with the ability of smart and android phones makes them serve as alternative to personal computers (Oladejo \& Yinus, 2013), and these have increased bank customers' interest to use the mobile banking services in Nigeria. 
According to Oladejo and Akanbi (2012), mobile operators have struggled to convert available features on personal computers to mobile devices. These outsourcing activities that were only being performed by personal computers to mobile phones have the potential to make bank customers to be deeply involved in mobile banking (Lai \& Li, 2015). In addition, improvement in telecommunication network, upon which e-banking generally relies in Nigeria, may engender bank customers to accept mobile banking services (Adewoye, 2013). In spite of this, little is known of the rate of mobile banking services adoption and challenges encountered in their adoption and usage in Nigeria. This knowledge would help banks identify barriers in using mobile banking services and to consciously address them. Thus, the necessity to fill the above research gaps aggravated the researcher to carry out this study.

\section{Research Problem}

Statistics showed that virtually all commercial banks have invested in mobile banking systems (Central Bank of Nigeria, 2015). Banks invest in technologies with expectation to reduce operational costs and improve service delivery (Siyanbola, 2013). Therefore, it is necessary to find out the degree to which customers have adopted mobile banking. Moreover, a lot of empirical research on some factors affecting customers' to adopt mobile banking services has been carried out in behavioral attributes such as; complexity, compatibility, relative advantage perceived security and observability, the result revealed a mixed findings, as such, some reveal a positive relationship (Mukhlis 2014; Luarn and Lin (2015), others revealed a negative relationship (Yeung 2015; Tuj Johara, 2014). However, little has been done on the demographic factors that affect customers' to adopt mobile banking services in Nigeria. Against this backdrop, this study therefore seeks to examine demographic factors affecting customers' to adopt mobile banking services in Benin-city, Nigeria.

\section{Research Questions}

Drawing upon the research problems stated above, this study examines demographic factors affecting customer's to adopt mobile banking services in Benin-city. The research question includes:

1. The level at which age affect the adoption of mobile banking services in Benin City?

2. The level at which gender affect the adoption of mobile banking services in Benin City?

3. To what extend do educational level affect the adoption of mobile banking services in Nigeria?

4. To what extend do occupation affect the adoption of mobile banking services in Nigeria?

5 The rate at which income affect the adoption of mobile banking services in Nigeria?

\section{The objectives of the study}

Broad objective

The broad objective is to examine how demographic factors affect customers' to adopt mobile banking services in Benin City.

Specific objectives are:

1.To carry out the extent to which age affect customers' to adopt mobile banking services in Benin City.

2.To ascertain whether gender have any effect on customer's towards the adoption of mobile banking services in Benin City.

3.To verify whether educational level have any effect on customers' to adopt mobile banking services in Benin City.

4.To verify whether occupation have any effect on customers' towards the adopting mobile banking services in Benin City.

5.To find out whether income level of customers have influence on customer's to adopt mobile banking services in Benin City.

\section{Hypotheses Development}

The null research hypotheses below be tested

$\mathrm{H}_{01}$ : Age does not significantly affect customers to adopt mobile banking in Benin City.

$\mathrm{H}_{02}$ : Gender does not significantly affect customers to adopt mobile banking in Benin City.

$\mathrm{H}_{03}$ : Education does not significantly affect customers to adopt mobile banking in Benin City. 
$\mathrm{H}_{04}$. Occupation does not significantly affect customers to adopt mobile banking in Benin City.

$\mathrm{H}_{05}$ : Income does not significantly affect customers to adopt mobile banking in Benin City.

\section{Literature Review}

\section{Mobile Banking Adoption}

According to Mukhlis, (2014), mobile banking is the newest among e-banking platforms. It refers to the technological method that permits customers to carry out different financial transactions with the help of mobile devices (Oladejo \& Yinus, 2013). The term mobile banking can be used in a broad sense to mean a financial transaction in technology while adoption drivers remain the focus of most researchers with an overload of mobile banking adoption models (Shaikh \& Karjaluoto, 2015). A high level of risk in the mind of the users to adopt mobile banking services is one of the great concerns that leads to failure of financial transactions (Luarn \& Lin, 2005; Riquelme \& Rios, 2010). Similarly, the significant impact of mobile banking on retail has facilitated cost reduction increase the quantity of data processing and improve operational performances (Laukkanen \& Lauronen, 2005).

It is a system (mobile banking) that uses technological innovative resources especially mobile phones that are java enabled, to effect financial transactions (Shih \& Fang, 2004). Mobile banking is a facilitator of banking transactions including a balance inquiry, payment of bill funds transfer through a mobile phone and (Shih \& Fang, 2004). It is the banking services offered to customers through java enabled mobile phones, allowing them to personally access bank accounts and perform various banking related transactions from anywhere and time in the world (Luarn \& Lin, 2015). It is simply bank transactions conducted with mobile phones or tablets. Put differently, it can be refers to as the availability of banking services to customers on their mobile phones. This definition is in line with Olalekan (2011) that defines mobile banking as "provisions of financial services using cellular phones.

However, mobile banking encompasses the use of mobile devices that enable bank customers to use virtual banking at any suitable and convenient time. Although it is unarguable that initial mobile banking activities were rendered through solicited messages (SMS), which was then called Short Message Services banking (Daniel, 1999). This means that mobile banking services has before now, most times been performed through SMS. But the speedy growth of the Android Operating System and various smart phones have given way to a huge increase in the use of a unique program called apps which when imputed to the device, will enables bank customers to access financial transactions. The mobile banking application has made it easier to process and execute financial functions with a mobile devise using the exact software programmed. Similarly, this precise code is commonly referred to as an App, and has made it possible for customers not only to view their account balances, transfer fund but also to carry out other financial actions such as payroll transactions and deposit their cheques over mobile device. Given the advancements in mobile web technologies, more banks, including the ones in Nigeria, have introduced mobile web based services not only to enhance local usage of mobile banking but also to strengthen customer relationships. A recent study found that over a third of banks adopted mobile banking because of the Wireless Application Protocol (WAP) and a Java enabled mobile phone network that made it easier to facilitate payments and funds transfer via mobile phones (Tuj Johara, 2014). With the new application downloaded on mobile phones, banks form alliance with telecommunication to provide easy and convenient banking services to their customers. However, this will only possible either by switching your bank or credit union's web page via the web browser on your mobile devise, through text messaging, or with the use of an app earlier downloaded to your mobile devise.

\section{Adoption of Innovation}

While innovation is an important factor of corporate performance, at the same time marketing which poised critical challenge to firms (Davis, 1986). Indeed, evidence emerged that innovations that do not meet or fulfill customers' needs but outweigh existing alternatives in terms of superiority and performance may not add desirable value to the firm (Bobbitt \& Dabholkar, 2001). Rogers (1995), adoption is customer's readiness or decision to subscribe and use mobile phones to perform financial transactions. It is a person's resolution to become a habitual user of an invention (mobile banking). The decision to use innovation develops over time and it simply stirs from positive feeling toward a product (Cheng \& Yeung, 2015), thus, adoption of mobile banking services could stir from attitude or feeling. According to Fishbein and Ajzen (1997) argue that attitudes towards behavior is made up of beliefs about attracting in the behavior and the related assessment of the credence. 
They argued that attitudes are learned disposition to recognize and operate constantly in a complimentary or uncomplimentary manner with regard to a specified ideal like a brand, product, and service. Attitude is reflected to be a learned tendency to react in a constantly complimentary or uncomplimentary manner with regard to a specified object which could be mobile banking services. Consequently, attitude toward mobile banking could be one's idea of the usefulness and willingness to adopt it. It could also be seen as one's complimentary or uncomplimentary attitude towards m-banking. That is an individual's evaluative feelings toward using mobile banking services.

\section{Theories of Adoption of Innovation}

\section{The Technology of Acceptance Model}

The Technology Acceptance Model was introduced in 1985 by Fred Davies. Fred opined those users' decisions to accept a technology innovation and continue using the system is contingent on his attitude, perceived ease of use and perceived usefulness. That is, the readiness that individuals will use or not use an innovation are contingent to his or her attitude which will further be impacted by perceived usefulness and perceived ease of use.

\section{The Theory of Planned Behavior (TPB)}

This theory was proposed by Icek Ajzen in 1985 as an expansion of the Theory of Reasoned Action (TRA). While the Theory of Reasoned Action assumes that the behavior of an individual or consumers are rational in gathering and analyzing information carefully and methodically and the outcomes of the evaluation reflect his/her intention to make actual use of technology or product" (McNeil, 2012), the Theory of Planned Behavior shows a situation where individuals lacks total power over their behavior which can be which was conked out further into one's further into one's proposed behavior and one perceived behavior. The theory (TPB) considered the behavioral intention as a being a function of attitude and subjective norms. (Fishbein \& Ajzen 1997; Taylor \& Todd, 1995).

\section{Innovation Diffusion Theory}

Another renowned theory suitable for predicting the adoption of mobile banking is the Innovation Diffusion Theory. Rogers (2003), considered innovation generally as the main determinant of business success and successful marketing. He further noted that lack of customer needs fulfillment over the existing alternatives to make new products fail to strive in the market. For a firm to be greatly In order for a firm to be triumphant in bringing innovation to the market, the potential customers must have a clear understanding of both the process and the factors that influencing the customers to adopt the innovation becomes a relevant consideration. Also, factors known as features of innovation are relative advantage, compatibility, and complexity. According to Rogers (2003), innovation combined with relative advantage, less complexity and compatibility can be rapidly adopted by an individual. He also stated that relative advantage and compatibility are key factors when innovation adoption pattern issues arise. According to Rogers (1995), innovation diffusion is in four stages; process, invention, diffusion He specifically defines adoption process as "a way in which an individual or other decisionmaking units moves from first knowledge of innovation to form an attitude towards the innovation, to a decision to adopt or reject, the execution of the new idea and the confirmation of the decision. In all, this process is made up of several actions and decisions over time whereby an individual considers a new idea and makes a decision either to integrate the new idea into his normal routine or not. The process is analyzed in figure 1. 


\section{Figure1. The Innovation Adoption Process}

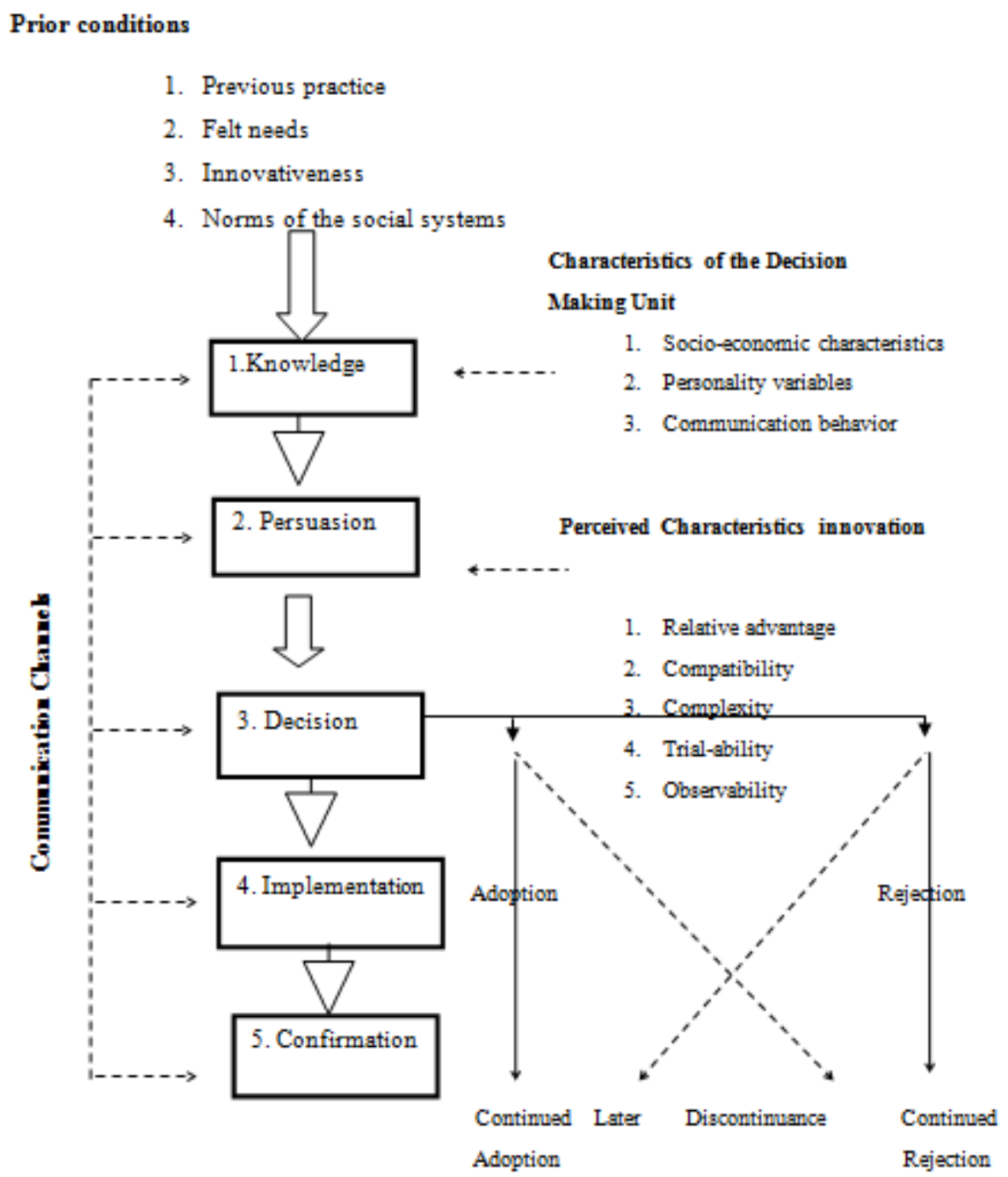

Source: Rogers (1995:14).

1. Knowledge is when an individual or some unit of decision-making body is showing an innovation's existence and how their feature works.

2. Persuasion is when an individual or some unit of decision-making body forms a good or bad attitude toward the innovation.

3. Decision implies when an individual or some unit of decision-making body engages in activities that follow the choice to adopt or reject the innovation.

4. Implementation occurs when an individual or some decision-making unit puts an innovation to use.

5. Confirmation is when an individual seeks reinforcement of an innovation-decision already made, or reverse a previous decision to adopt or reject the innovation if exposed to conflicting messages about the innovation.

\section{Innovation Adoption Model}

The innovation adoption model stressed that consumers' readiness to adopt an innovation is a reflection of their ability, role clarity, and motivation. This is further broken down into six stages which are awareness, investigation, evaluation trial, repeated use, and commitment. awareness, investigation, evaluation, trial, repeated use, and commitment. 
Figure 2: Model of Innovation Adoption

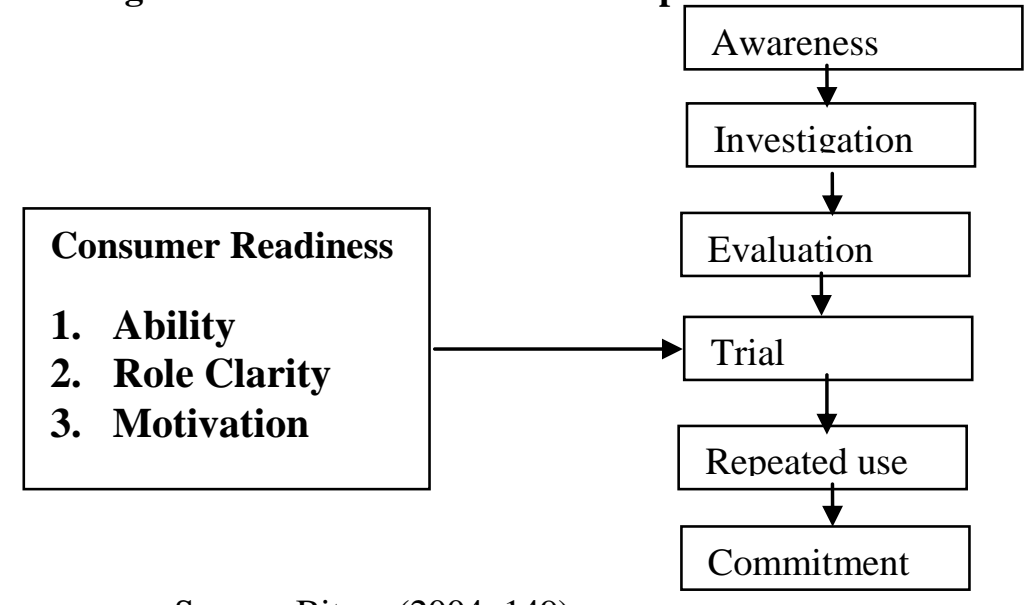

Source: Bitner (2004: 149)

First, is the awareness that the innovation exists. Then they may likely collect additional information concerning the innovation to form the basis for a conclusive judgment. If judged to be appealing, then there is the possibility of trial. This trial may lead to repeated use and commitment, depending on the customer's perception and experience with the innovation. They emphasized trial as a distinct stage in because of its impact on customers' decisions. However, Antil (1988) is of the opinion that customers do not move directly from the trial state to the decision stage but emphasized that presence of consequences and confirmation stages which according to him might lead to a decision to either reject or adopt the innovation.

Figure 3: Modification to Trial-Adoption Process

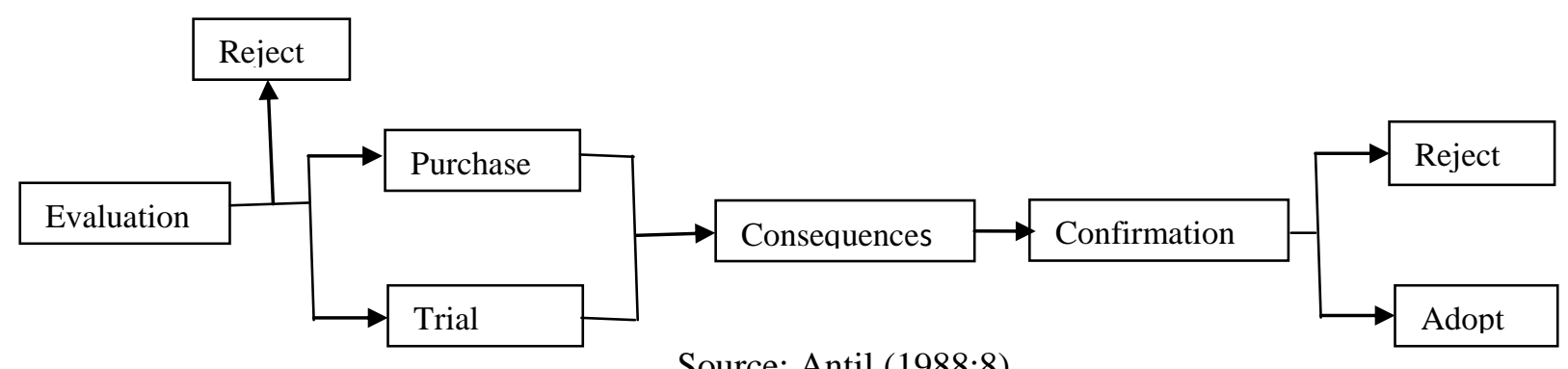

Source: Antil (1988:8)

\section{Empirical Studies on the E-Banking Services}

Several studies have investigated the adoption of various e-banking services. Olalekan (2011) conducted a study on e-banking patronage. The study found that significant differences exist in electronic banking patronage and customer satisfaction between genders in Nigeria. Agwu and Carter (2014), empirically examined mobile phone banking benefits, problems, and prospects in Nigeria. The study employed interview to elicit information from bank staff, customers and students from higher educational institutions. The findings of the study showed that phone banking was more established than internet banking and ATM services, but ATM services had a wider reach. However, cost and maintenance of mobile banking, education of customers, poverty and infrastructure unavailability are problems associated with m-banking services.

Idris (2013) explored the barriers to the adoption of mobile banking services in Ghana. Is was discovered that users of mobile banking services are very low and reasons for rejecting mobile banking were that mobile banking requires knowledge and learning, it attracts additional bank charges and there is poor telecommunication network. All these made consumers to prefer traditional means of banking instead of mobile-enabled banking services. Aliyu, Younus and Tasmin (2012) investigated factors affecting consumer adoption of electronic banking in Nigeria. The study collected information using questionnaire from bank customers in Bayero University Kano, in northern Nigeria. The results of their study revealed that perceived usefulness and reluctant to change have effects. Ease of use, awareness, security, cost, accessibility, and reluctance to change affect usage of e-banking in Nigeria. Eze, Yaw, Manyeki and Har (2011) conducted a study on the factors that influence the use of internet banking services among young Malaysian adults. 
The study applied the extended Technology Acceptance Model with six independent variables, and used convenience-sampling method and questionnaire to collect data. The study found that perceived security, perceived usefulness, self-efficacy, perceived ease of use, relative advantage, and trial-ability affect consumers adoption of mobile banking.

Olatokun and Igbinedion (2009) studied the adoption of Automatic Teller Machines (ATMs) in Nigeria. The study used convenient sampling and questionnaire to collect information from bank customers in Jos, Plateau state, Nigeria. The study found that constructs of innovation diffusions theory which include relative advantage, compatibility, complexity and trial-ability all had a significant effect on customer attitude towards the use of ATM. Aboelmaged and Gebba (2013) applied Technology Acceptance Model (TAM) and the Theory of Planned Behavior (TPB) on the adoption of mobile banking. The study collected needed data from 119 bank customers and analyzed them with multiple regressions. The results of the study revealed that behavioral control, perceived ease of use and perceived usefulness do not impact on attitude toward mobile banking, however, subjective norm significantly and positively affect attitude toward mobile banking Govender and Sihlali (2014) examined the adoption mobile banking among college students. The study specifically, investigated the factors that influence the adoption of mobile banking services by students. Based on the constructs of TAM which the study tested on mobile services, it was found that perceived value, perceived trust, social influence and perceived ease of use account for about $40 \%$ of the descriptive power of the dependent variable. Also, the findings showed that trust and perceived value influence students' willingness to use m-banking and only perceived trust positively motivates students to continue the use of m-banking services.

Mukhlis (2014) empirically investigated the effect of some attributes of diffusion of innovation model (compatibility, trial-ability and relative advantage) toward intention to use mobile banking through the consumer attitudes among bank's mobile banking users in Banda Aceh. The study adopts purposive sampling and the data collected from the respondents were analyzed using path analysis technique. The results of Mukhlis (2014) study revealed that relative advantage; compatibility and trial ability directly had significant effect on consumer attitudes in a positive way. The study also revealed that trial-ability and relative advantage was significant toward intention to use mobile banking. However, compatibility was not significant toward the intention to use mobile banking positively.

\section{Mobile Banking in Nigeria}

The mobile banking services have persistently growing over the years partially in developed countries (Agwu, \& Carter, 2014). It has been noted that while there are seven billion inhabitant in the world, six billion have mobile phones, two billion have bank accounts and over thirty-three percent of total number of mobile phone users holding bank account surveyed globally reported to have adopt mobile banking in the past 12 months preceding 2014 (Mobile Marketing Association (MMA), 2014).

In Nigeria, it has been reported that only 5.7 million have mobile banking platform as at 2013 (CBN, 2015). Although 5.7 million users of mobile banking is small compared to over 40 million banks account holders and 132 million phones users (CBN, 2015), statistics showed improvement in technological infrastructure in Nigeria and the introduction of android phones promises improvements in m-banking growth (Siyanbola, 2013). It has also been indicated that various banks in Nigeria have rolled out deferent mobile banking services mobile to suit the needs and style of their customers (Agwu \& Carter, 2014). For examples, Guarantee Trust Bank (GTB) and United Bank for Africa (UBA) launched Mobile Banking with collaboration with networks providers that allow customers to fund accounts, transfer and receive money from other accounts or from western union money transfer or money gram. In addition, First bank has mobile Banking services which allow customers to send and receive money from mobile phones.

The First Bank Mobile Money Service called FIRSTMONIE also allows customers to send or receive money, buy airtime and pay bills on their mobile devices without a bank account. The uniqueness of the First mobile banking services is that customers can fund his account from First Monie Account through ATM by inserting card, PIN and selecting the send money option. This transaction does not required android phones.

\section{Benefits of Mobile Banking Services}

The revolution of mobile banking has produced a radical change in the manner that banking transaction was carried out. Banking services have become faster and more convenient with easy accessibility with the introduction of mobile banking. 
Similarly, mobile banking appears to have reduced the amount of time spent by customers on transactions, made transactions convenient and easy for customers. The easy access to bank account reduces the worry of visiting the bank's branch thereby making transactions doable anywhere regardless of where the branch is situated (Cheng \& Yeung, 2015). The advent of mobile banking thus has brought opportunity for bank customers to experience convenient way of business transactions (Oladejo, \& Yinus, 2013).

To justify the advantages of mobile banking services to banks and its customers in Nigeria, empirical studies found that mobile banking have significantly improved banks performance and translate positively to customers' satisfaction (Adewoye, 2013; Oladejo \& Yinus, 2013). With the introduction of mobile banking, banking is no longer limited by time or location. Adopter of m-banking can carry out their transaction from anywhere and complete transactions regardless of the domiciled branch. Indeed, Luarn and Lin (2015) alluded that "mobile banking services have the potential to make users across the world to have moderately easy access to their accounts 24 hours per day, seven days a week". Therefore, mobile banking services show promise for bank growth and financial inclusion particularly in Nigeria given their capability to contact larger users regardless of their direction, which can in turn encourage customers' loyalty. Other benefits of mobile banking to banks include the operational cost reduction, ability to attract new customer including those in rural areas if enlightened, and minimize transactions errors.

\section{Challenges of Mobile Banking Services}

Mobile banking in Nigeria is facing many challenges just as its prospect looks bright. The ability to identify the challenges confronting or that will confront a phenomenon and proffer or prepare solutions for them is what ensures the success of such a phenomenon. The challenges confronting e-banking and invariably, mobile banking in Nigeria include: deficit in financial infrastructure, poor power supply, prevalence of electronic fraud, low literacy level, religious beliefs and poor network communication (Oladejo \& Akanbi, 2012). Similarly, human capacity building and sufficient level of infrastructure are required by developing countries before they can accept a global technology like mobile banking. For example, study showed that working capital, adequate infrastructure and required technical expertise are lacking for effective implementation of m-banking services (Tunji, 2013). Siyanbola (2013) noted that unavailability of network is a major problem facing GSM and the internet consumption in Nigeria. This is no doubt affects the policy the policy as users have problem carrying out their transactions at their convenient time (Siyanbola, 2013). Poor network sometimes make customers to move from one place to another to make call let alone perform mobile banking services. This could negatively affect banks customers' level of mobile banking adoptions.

With the increasing usage of the mobile banking services, abuse of privacy becomes a major concern of most of the users (Oladejo, \& Yinus, 2013). It has been noted that anonymity features of mobile banking play an important role in privacy protection but could be compromised when users of mobile banking services enter their personal identification number to make payments (Olalekan, 2011). "As bank customers prefer to keep the details of their transaction private, they may be forced to use them in performing mobile banking services resulting in risk of e-money fraud" (Olalekan, 2011). Egwali (2008) conducted a study on the Security Indicators in Nigeria. It was found that security indicators were not very helpful at alerting and protecting users from revealing sensitive personal information to spoofed e-banking sites.

From the forgoing, high level of fraudulent activities through e-banking is a challenge which the entire banking industry must resolve before cashlite policy can be effective (Siyanbola, 2013). According to Oladejo and Yunus (2008), "in the global networks, mobile banking users may be vulnerable to risk or can never avoid the risk of crime entirely". This is because e-banking has made fraud pattern to change. There seems to be an increase in electronic transaction fraud and computer crime (Yahoo boys, Hackers, etc) in Nigeria. The prevalence of e-fraud has made many to prefer to incur the costs of cash transactions rather than use m-banking and e-payment systems. In addition, many bank customers do not have the necessary financial muscle to handle both gadgets and data required for $\mathrm{m}$-banking and hence a general decline in the adoption of $\mathrm{m}$-banking. Indeed, income level has been found to predict adoption of e-banking services (Mukhlis, 2014).

\section{Methodology}

The research design adopted ex-post-facto method since it seeks to ascertain the influence of one or more independent variables on a dependent variable without the opportunity to vary or manipulate the independent variables. 
The study made use of primary data which was obtained from the sampled respondents through the use of a questionnaire. The population of the study consists of all commercial bank individual customers in Benin City, Edo state. We randomly selected our sample size from the population which is a comprehensive list of all individual bank customers in Benin City. Because such list was not available, we had to work with a sample size of 600 .

For the Sampling Technique, there are four Local Government Areas in Benin City, namely, Oredo, Egor, Ikpoba Okha and Ovia North East. These form our strata for bank selection. There are 58 branches of commercial banks in Oredo Local Government, 21 in Egor, 16 in Ikpoba Okha and 9 in Ovia North East Local Government Area (all in Benin City). Working with 20\% of banks in each local government area, we arrived at 11, 4, 3 and 2 branches for Oredo, Egor, Ikpoba Okha and Ovia North East local government respectively making a total of 20 banks.

The simple random sampling method was used to pick the required number of branches in each local government. For Oredo, 58 pieces of paper of equal sizes were cut and labeled with the name of each of the bank branches. The papers were folded to equal sizes and placed in a basket. A blind folded assistant was called upon to pick a paper from the basket one at a time. The basket was shaken together after each pick until 11 branches had been picked. The same method was used for Egor, Ikpoba Okha and Ovia North East.

To examine whether age, gender, educational level, occupation and income of customers have any influence on adoption of mobile banking services, we analyzed with ANOVA and independent t-test. Specifically, ANOVA was used to test the influence of age, educational level, occupation and income on the adoption of mobile banking while the independent t-test was used to test the influence of gender on the adoption of mobile banking. All tests (analysis) were done at 5\% level of significant using SPSS 20.0. The internal reliability and the Cronbach's alpha was calculated and were all greater than 0.7 , a level considered acceptable.

\section{Data Presentation, Analyses and Interpretation}

\section{Description of Respondents' Demographics}

This section contains information about the demographics respondents of the study. The demographic variables include: gender, age educational level, monthly income and occupational status of respondents. The result is presented in table 1 .

Table : 1 Respondents Demographics

\begin{tabular}{|c|c|c|}
\hline \begin{tabular}{|l|l|} 
S/Nariables \\
\end{tabular} & Frequency & $\%$ \\
\hline \multicolumn{3}{|l|}{ Gender } \\
\hline \begin{tabular}{|l|l|}
1 & Male \\
\end{tabular} & 297 & 49.5 \\
\hline 2 Female & 287 & 47.8 \\
\hline 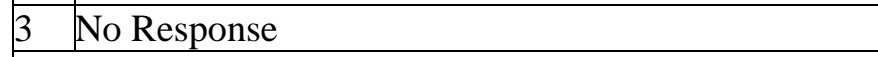 & 16 & 2.7 \\
\hline Total & 600 & 100 \\
\hline \multicolumn{3}{|l|}{ Age } \\
\hline \begin{tabular}{|l|l|}
1 & $18-24$ Years \\
\end{tabular} & 228 & 38.0 \\
\hline $2 \quad 25-30$ Years & 134 & 22.3 \\
\hline $3 \quad 31-35$ Years & 53 & 8.8 \\
\hline \begin{tabular}{|l|l|}
4 & $36-44$ Years \\
\end{tabular} & 72 & 12.0 \\
\hline \begin{tabular}{|l|l|}
5 & $45-54$ \\
\end{tabular} & 79 & 13.2 \\
\hline \begin{tabular}{|l|l|}
6 & 55 years and above \\
\end{tabular} & 11 & 1.8 \\
\hline \begin{tabular}{l|l}
7 & No Response \\
\end{tabular} & 23 & 3.8 \\
\hline Total & 600 & 100 \\
\hline \multicolumn{3}{|l|}{ Educational Qualification } \\
\hline $1 \quad$ Primary School Certificate & 7 & 1.2 \\
\hline 2 Secondary School Certificate & 147 & 24.5 \\
\hline 3 Ordinary Diploma/National Certificate of Education & 92 & 15.3 \\
\hline 4 Higher National Diploma & 72 & 12.0 \\
\hline 5 Bachelor Degree & 156 & 26.0 \\
\hline 6 Postgraduate degree (PGD, Masters, Ph.D & 30 & 5.0 \\
\hline \begin{tabular}{|l|l|}
7 & Professional certificate \\
\end{tabular} & 54 & 9.0 \\
\hline
\end{tabular}




\begin{tabular}{|l|l|l|l|}
\hline 8 & No Response & 42 & 7.0 \\
\hline \multicolumn{2}{|l|}{ Total } & $\mathbf{6 0 0}$ & $\mathbf{1 0 0}$ \\
\hline Monthly Income & 265 & 44.2 \\
\hline 1 & Below 50,000 & 115 & 19.2 \\
\hline 2 & N50,001- 100,000 & 46 & 7.7 \\
\hline 3 & N100,001-150,000 & 23 & 3.8 \\
\hline 4 & N150,001 - 200,000 & 22 & 3.7 \\
\hline 5 & N200,001 -N400,000 & 27 & 4.5 \\
\hline 6 & N400,001 and Above & 102 & 17.0 \\
\hline 7 & No Response & $\mathbf{6 0 0}$ & $\mathbf{1 0 0}$ \\
\hline Total & & \\
\hline Occupational status & 195 & 32.5 \\
\hline 1 & Student & 138 & 23.0 \\
\hline 2 & Self Employed & 79 & 13.2 \\
\hline 3 & Civil/public servant & 156 & 26.0 \\
\hline 4 & Private sector employee & 32 & 5.3 \\
\hline 5 & No Response & $\mathbf{6 0 0}$ & $\mathbf{1 0 0}$ \\
\hline Total & & \\
\hline
\end{tabular}

Source: Researcher's field Work (2015)

\section{Gender of respondents}

A close look at table 1 revealed that 297 (49.5\%) were male, while 287 (47.8\%) were female. This finding indicates that majority of the respondents were male though not substantial.

\section{Age of respondents}

Table 1 indicated that $228(38 \%)$ of the total respondents fell into age group of 18- 24 years. This group constituted majority of the respondents, followed by age group of 25-30 years, 45-54years and 36-44years which accounted for $134(22.3 \%), 79(13.2 \%)$ and $72(12 \%)$ of the total respondents respectively. The remaining age groups 31-35years and 55 years and above constituted 53(8.8\%) and 11(1.8) \% of the total respondents respectively.

\section{Educational Qualification of respondents}

As showed in table 1 above, 156(26\%) were bachelor degree holders. This group accounted for majority of the respondents. $147(24.5 \%)$ were secondary school certificate holders. 92(15.3\%) were Ordinary Diploma/National Certificate of Education holders. 72(12\%) were Higher National Diploma holders. 30(5\%) and 54(9.0\%) were Postgraduate Degree (PGD, Masters or Ph.D.) and Professional certificate holders respectively. The least respondents 7(1.2\%) hold Primary School Certificate. The results of the educational levels of the respondents suggest that the respondents possess enough education to be able to provide useful and objective answers to the items in the questionnaire.

\section{Monthly Income}

As revealed in Table: 1 above, 265(44.2\%) respondents earned below N50, 000 monthly. 115(19.2\%) respondents earned between N50, 000 and N100, 000 monthly. 46(7.7\%) respondents earned between N100, 0001 and N150, 000 monthly. 23(3.8)\% respondents earned between150, 0001 and 200,000 monthly. 22(3.7\%) respondents earned between 200, 0001 and 400, 000 monthly. 27(4.5\%) respondents earned between 400000 and above every month. From the above findings, majority of the respondents earn below N50, 000 monthly incomes, thus indicating the level of poverty in Benin City.

\section{Occupational status}

Table 1 above showed that 195(32.5\%) were students, 138(23\%) were self employed, 76(13.2\%) were civil servants and 156(26\%) were employed by private firms. Majority of the respondents were students.

\section{Influence of Demographics on Adoption of Mobile Banking Services}

The objective of the study is to study the demographic factors; age, education, income, gender and occupational status of respondents on the adoption of mobile banking services tested with multiple regressions. 
But chi-square was employed to test the control of gender on the adoption of mobile banking services. The summary of the influence of age, education, income and occupational status on the adoption of mobile banking is presented in table 1 while the influence of gender on the adoption of mobile banking services is presented in table 2 .

Table 2 Influence of demographics on adoptions of mobile banking services

\begin{tabular}{|l|l|l|l|l|l|}
\hline \multirow{2}{*}{ Model } & \multicolumn{2}{|l|}{ Unstandardized Coefficient } & $\begin{array}{l}\text { Standardized } \\
\text { Coefficients }\end{array}$ & T & Sig. \\
\cline { 2 - 4 } & $\mathrm{B}$ & Std. Error & Beta & & \\
\hline (Constant) & 1.645 & .050 & & 33.044 & .000 \\
Age & -.070 &. .014 & -.220 & 4.990 & .000 \\
Education & .012 & .012 & .044 & 1.015 & .310 \\
Income & .045 & .015 & .137 & 2.921 & .004 \\
Occupation & .098 & .017 & .254 & 5.793 & .000 \\
\hline
\end{tabular}

a. Dependent Variable: Adoption

$\mathrm{R}=.338, \mathrm{R}^{2}=.112$, Adjusted $\mathrm{R}^{2}=.106$, Std error of the estimate $=.472$, Durbin-Watson= 1.969, F-Statistics 15.276, prob. (F-statistics) $=0.0000$.

Source: Researcher's field Work (2015)

The regression results in table 2 revealed adjusted values of $\mathrm{R}$ squared of .106. This indicates that 10.6 percent of changes in the adoption of mobile banking were captured by the demographic variables (age, education, income and occupational status). The regression model specifically indicates that age, education, income and occupational status jointly explain $10.6 \%$ of the systematic variation in the adoption of mobile banking services in Benin City. The remaining $89.4 \%$ is explained by other elements not included in the model. The significance of the F-value at the 5 percent level implies that the demographic factors as group are actually relevant in explaining the adoption of mobile banking services by the respondents. The Durbin-Watson statistic of 1.969 in the model suggests the absence of autocorrelation along with its serious consequences.

At individual level, the regression results revealed that age, income and occupational status are significant at $\mathrm{P}<0.05$, hence influence adoption of mobile banking services. The regression results revealed that age negatively but significantly affect the adoption of mobile banking services, income positively and significantly influence the adoption of mobile banking services and occupation positively and significantly affect the adoption of mobile banking services. However, educational qualifications failed the significance test at the 5 percent level, thereby implying that this factor is not effective in influencing the adoption of mobile banking services in Benin-City. The negative finding on influence of age implies that as individuals aged the less likely he/she will adopt mobile banking services. This result is interesting given that young people appear to be more abreast and inclined to innovation than older people. Similarly, the positive influence of income on adoption of mobile banking means that as income increases the more the adoption of mobile banking services. This finding is not surprising since it is usually people who have money in their bank account that will be willing to adopt mobile banking to ease the transfer of money from their bank account to another or to carry on other banking transactions. Thus, wealth and adoption of innovation are highly related. In addition to this, the positive influence of occupational status on adoption of mobile banking services denotes that as an individual transgresses from being a student and unemployed to self employed and employee of public or private sectors, the more he/she is likely to adopt mobile banking services. 


\begin{tabular}{|c|c|c|c|c|c|c|c|}
\hline \multicolumn{6}{|c|}{ GENDER * Adoption Cross tabulation } & \multicolumn{2}{|c|}{ Chi-Square Tests } \\
\hline & & & \multicolumn{2}{|l|}{ Adoption } & \multirow[t]{2}{*}{ Total } & \multirow[t]{2}{*}{$\mathrm{F}$} & \multirow[t]{2}{*}{ Sign } \\
\hline & & & Adopters & Non Adopters & & & \\
\hline \multirow{12}{*}{ GENDER } & \multirow{4}{*}{.00} & Count & 3 & 13 & 16 & \multirow[t]{16}{*}{2.772} & \multirow[t]{16}{*}{.096} \\
\hline & & Expected Count & 8.5 & 7.5 & 16.0 & & \\
\hline & & $\%$ within GENDER & $18.8 \%$ & $81.3 \%$ & $100.0 \%$ & & \\
\hline & & $\%$ within Adoption & $0.9 \%$ & $4.6 \%$ & $2.7 \%$ & & \\
\hline & \multirow{4}{*}{ Male } & Count & 179 & 118 & 297 & & \\
\hline & & Expected Count & 156.9 & 140.1 & 297.0 & & \\
\hline & & $\%$ within GENDER & $60.3 \%$ & $39.7 \%$ & $100.0 \%$ & & \\
\hline & & $\%$ within Adoption & $56.5 \%$ & $41.7 \%$ & $49.5 \%$ & & \\
\hline & \multirow{4}{*}{ Female } & Count & 135 & 152 & 287 & & \\
\hline & & Expected Count & 151.6 & 135.4 & 287.0 & & \\
\hline & & $\%$ within GENDER & $47.0 \%$ & $53.0 \%$ & $100.0 \%$ & & \\
\hline & & $\%$ within Adoption & $42.6 \%$ & $53.7 \%$ & $47.8 \%$ & & \\
\hline \multirow{4}{*}{ Total } & & Count & 317 & 283 & 600 & & \\
\hline & & Expected Count & 317.0 & 283.0 & 600.0 & & \\
\hline & & $\%$ within GENDER & $52.8 \%$ & $47.2 \%$ & $100.0 \%$ & & \\
\hline & & $\%$ within Adoption & $100.0 \%$ & $100.0 \%$ & $100.0 \%$ & & \\
\hline
\end{tabular}

With respect to the influence of gender on the adoption of m-banking services, Table 3 revealed F-statistics of 2.772 and p-value of 0.096 which is greater than $5 \%$ level of significance. This revelation indicates that gender has a weak influence on adoption of mobile banking services.0 cells $(0.0 \%)$ have expected count less than 5 . The minimum expected count is 7.55

Source: Researcher's field Work (2015)

\section{Hypotheses Testing}

$\mathrm{H}_{0}$ : Customers' demographics variables (age, gender, educational qualification and level of income) do not impact on the adoption of mobile banking in Benin-City.

$\mathrm{H}_{1}$ : Customers' demographics variables (age, gender, educational qualification and level of income) do impact on their adoption of mobile banking in Benin-City.

From the results in table 2, age, income and occupational statues had p-value of $.000, .004$ and .000 respectively (their individual p-values are less than 0.05 (5\% level of significance). Based on these findings, we reject the null hypothesis and accept the alternative hypotheses which state that demographics such as age, income and occupational status do impact the adoption of mobile banking services. However, educational qualification had is probability value of .310 which is greater than $5 \%$ level of significant. Thus, we accept the null hypothesis and reject the alternative hypothesis which states that educational qualification significantly influence on adoption of mobile banking services. Similarly, we accept the null hypothesis and reject the alternative hypothesis which states that gender has a significant impact on the adoption of $\mathrm{m}$-banking services in Benin-City, since gender had F-statistic of 2.772 and p-value of .096 which is greater than $5 \%$ level of significant.

\section{Discussion of Findings}

This study which aimed at ascertaining the influence of demographic variables on adoption of mobile banking services revealed that age, income and occupational status have significant influence on adoption of mobile banking services. However, gender and educational qualification were found not to exhibit significant effect on adoption of mobile banking services.

The findings of this study which revealed the negative effect of age and positive effect of income on adoption of mobile banking is consistent with several previous studies (Rogers 1995; Mattila, 2003; Sohail \& Shanmugham 2003; Goi, 2005; Flavián, Guinaliu \& Gurrea, 2006; Govender \& Sihlali, 2014; Tuj, 2014). The negative influence of age implies that as individuals aged the less likely he/she will adopt mobile banking services. This result is interesting given that young people appear to be more abreast and inclined to innovation than older people. 
Rogers (1995) have earlier found that because young people are generally tend to be more literate, have higher social status, seek higher occupational status and have greater degree of upward social mobility they are more likely to adopt innovation. Similarly, Goi (2005) has revealed that adopters of innovation are often relatively younger. They are typically young, affluent and wealthy (Govender \& Sihlali 2014). Tuj (2014) and Sohail and Shanmugham (2003) have also concluded that "young and affluent people are more likely to use internet banking services in Malaysia". In addition, Flavián, Guinaliu and Gurrea (2006) reported that "in Chile, older and lower income groups are less likely to conduct their banking operations using the Internet". The findings of this study which showed that as income increases the more the adoption of mobile banking services is not surprising given the fact that it is usually people who have money in their bank account that will be more likely to find better ways to ease the transfer of money from one bank account to another rather than rely on brick and mortal banking systems. Similarly, in the current economic situation in the country, direct and indirect cost associated with the use of mobile banking services could discourage or pull back intending low income earners to adopt it. Innovation like mobile banking services is often rejected among low income earners since it offers a greater avenue for adopters to spend easily.

Furthermore, this study which revealed no significant effect of gender on mobile banking services is contrary to Gao and Owolabi (2008) study that found that female respondents are more likely to adopt Internet banking than males in Nigeria. More so, another finding of this study which revealed that educational qualification do not significantly affect the adoption of mobile banking services is contrary to earlier study by Goi (2005) that demonstrated that less-educated people are less likely to use Internet banking. Mattila (2003) has also found that internet banking users in Finland are relatively wealthy, highly educated, and are in higher professions. However, the advancement of socio media platforms occasioned by technology progress has apparently bridged illiteracy gaps. This could have the capacity to pull back the effect of educational qualification on adoption of mobile banking services. This assertion is consistent with recent study that found that the use of social media has gained much ground of learning and educating people irrespective of gender than formal education ( $\mathrm{Lai} \& \mathrm{Li}, 2015$ ). In Nigeria, many people whether formally or not formally educated are connected to Face book, WhatApp and Instagram for enlightenment and information which, appear to account for the insignificant difference among the levels of education on adoption of mobile banking services.

\section{Contribution to Knowledge}

Most of the available studies on demographics' influence on mobile banking adoption are of foreign origin. This study therefore, is a harbinger providing empirical evidence in Nigeria on the relationship between demographics and the adoption of mobile banking services in Nigeria relevant to theory building.

\section{Recommendation}

1. Banks should design or develop mobile banking services application that is easy to use and navigate. This may help to enhance customers' blissful interaction with mobile banking services.

2. Government should exempt transactions carried out with the use of mobile phones from the current fifty naira stamp duty charges.

3. Finally, bank's staff should be exempted from all mobile banking related charges. This will encourage them to adopt, use and have adequate knowledge of the product for effective selling.

\section{Conclusion and Future Direction}

Demographic characteristics such as age, gender, income level and occupational status influence the adoption of mobile banking services in Benin City. However, educational status had no significant influence on the adoption of mobile banking services in Benin City.

\section{References}

Abdulkadir, N., Galoji, S.1, \& Razak, R. (2013). An Investigation into the Adoption of Mobile Banking in Malaysia. International Journal of Business and Commerce, 3(3), 153-158.

Aboelmaged, M. G. \& Gebba, T.R. (2013). Mobile Banking Adoption: An Examination of Technology Acceptance Model and Theory of Planned Behaviour. International Journal of Business Research and Development. 2(1), 35-50. 
Adewoye, J. O. (2013), Impact of mobile banking on service delivery in the Nigerian Commercial Banks. International Review of Management and Business Research, 2(2), 333, 344

Agwu, E., \& Carter, A. (2014). Mobile Phone Banking In Nigeria: Benefits, Problems and Prospects. International Journal of Business and Commerce, 3(6), 50 - 70.

Alabar, T.T. (2012). Electronic banking services and customer satisfaction in Nigerian banking industry. International journal of business and management tomorrow, 2(3), 1-8.

Aliyu, A.Younus, A., \& Tasmin, M.D. (2012). An exploratory study on adoption of electronic banking: underlying consumer behaviour and critical success factors: Case of Nigeria. Business and Management Review, 2(1), $01-06$.

Antil, J.H. (1988), New Product or Service Adoption: When Does it Happen? The Journal of Consumer Marketing, 5(2), 5-16.

Bandura, A. (1977). Self-efficacy: toward a unifying theory of behavioral change. Psychological review, 84(2), 191-102.

Bandura, A. (1982). Self-efficacy mechanism in human agency. American psychologist, 37(2), 122-132.

Benamati D., \& Serva F. (2007). Trust and Distrust in Online Banking: Their Role in Developing Countries. Information Technology for Development, 13(2) 161-175

Bitner, Mary; Ostrom, Amy; and Neuter, Matthew (2002). "Implementing Successful Self-service Technologies," Academy of Management Executive, November, 16 (4) 96-109.

Bobbitt, L.M. \& Dabholkar, A. (2001). Integrating attitudinal theories to understand and predict use of technology-based self-service', International Journal of Service Industry Management, 12(5), 423-450.

Bultum, A. G. (2015). Factors affecting adoption of electronic banking system in Ethiopian Banking Industry. Journal of Management Information System and E-commerce, 1(1), 12-20.

CBN (2015). Guidelines on electronic banking in Nigeria. Chartered Bank of Nigeria, USA.

Celik, H. (2008). What determines Turkish customers' acceptance of internet banking? Marketing Journal, 26 (5), 353-370

Cheng, L., \& Yeung. L. (2015) Adoption of Internet Banking: An Empirical Study in Hong Kong, Decision Support Systems, 42(3), 1558-1572.

Chiemeke, S.C., Evwiekpaefe, A.E., \& Chete, F.O. (2006). The adoption of Internet banking in Nigeria: an empirical investigation. Journal of Internet Banking and Commerce, 11(3), 41-53.

Davis, F. D. (1989). Perceived usefulness, perceived ease of use and user acceptance of information technology. MIS Quarterly, 13 (3), 319-40.

Davis, F. D., Bagozzi, R. P., \& Warshaw, P. R. (1989). User acceptance of computer technology: A comparison of two theoretical models. Management Science, 35(8), 982-1003.

Egwali, A. O. (2008). Customers Perception of Security Indicators in Online Banking Sites in Nigeria. Journal of Internet Banking and Commerce. 13(3), 85-94.

Etim, S. O. (2000). The risks of electronic banking. A Paper Presented at Centre for Insurance Research Luncheon, Lagos.

Eze, U. C., Yaw, Manyeki, L.H., \& Har, L. (2011). Factors affecting internet banking adoption among young adults: evidence from Malaysia. International Conference on Social Science and Humanity, 5(2), 23-34.

Fishbein, M., \& Ajzen, I. (1997). Belief, Attitude, Intention, and Behavior: An Introduction to Theory and Research. Reading, MA: Addison-Wesley.

Flavián, C., Guinalíu, M., \& Gurrea, R. (2006). The influence of familiarity and usability on loyalty to online journalistic services: The role of user experience. Journal of Retailing and Consumer Services, 13(5), 363-375.

Gao, P. \& Owolabi, O. (2008). Consumer adoption of internet banking in Nigeria. International Journal of electronic finance, 2(3), 284-299.

Goi. C.L. (2005). E-Banking in Malaysia: Opportunity and Challenges. Journal of Internet Banking and Commerce, 10(3), 30-41.

Govender, I., \& Sihlali, W. (2014). A study of mobile banking adoption among University Students. Mediterranean Journal of Social Sciences, 5(7), 451-458.

Hill, T., Smith, N. D., \& Mann, M. F. (1986). Communicating innovations: Convincing computer phobics to adopt innovative technologies. Advances in Consumer Research, 13(1), 419-422. 
Idris, F. (2013).Barriers to adoption of mobile banking: evidence from Ghana. International Journal of Academic Research in Business and Social Sciences, 2(13), 3-7.

Imiefoh, P. (2012). Towards effective implementation of electronic banking in Nigeria. An International Multidisciplinary Journal, 6 (2), 290-300.

Lai, W., \& Li, C. (2015). Technology Acceptance Model for Internet Banking: An Invariance Analysis, Information \& Management, 42(2), 373-386.

Luarn, P. \& Lin, H.H (2015). Toward an understanding of the behavioral intention to use mobile banking," Computers and Human Behavior, 1(21), 73-91.

Mattila, M. (2003) Factors Affecting the Adopting of Mobile Banking Services. Journal of Internet Banking and Commerce, 8, 8-12.

McNeil, H. D. (2012). Older adults' perceptions of financial technologies. Retrieved on $16^{\text {th }}$ June, 2015 from http://digitalcommons. mcmaster.ca/cgi/viewcontent.cgi?article.

Mukhlis, Y. (2014). Diffusion of innovation, consumer attitudes and intentions to use mobile banking. Information and Knowledge Management, 4(10), 12-18.

Nyeko, J. S. Moya, M., Kabaale E., \& Odongo, J.(2014). Factors influencing the Short Message Service (SMS) mobile banking adoption: a users' perspective in the West Nile Region in Uganda. Journal of Business and Commerce, 2(4), 56-64.

Oladejo, M., \& Akanbi .T (2012). Bankers' perceptions of electronic banking in Nigeria: A review of post consolidation experience. Research journal of financial and accounting, 3(2), 1-11.

Oladejo, M.O. \& Yinus, O. (2013). Does mobile banking influence service delivery? An Empirical Investigation of the Nigerian Money Deposit Banks. Journal of Management and corporate governance, 5(1), 50-69.

Olalekan, A. (2011). E-banking patronage in Nigeria: an exploratory study of gender difference. Business Intelligence Journal, 4(3), 65-70.

Olatokun, W.M., \& Igbinedion L. J. (2009). The adoption of automatic teller machines in Nigeria: an application of the theory of diffusion of innovation. Issues in informing science and information technology volume, 6(3), 9- 23.

Oluochi, R. A., Ajaja, P. O., \& Nwangi, J. (2015). Factors affecting adoption of mobile banking technology in Kenya, Asian Journal of Business and Management Sciences, 2(11), 01-13.

Polatoglu, V. N. \& Ekin, S. (2001). An Empirical Investigation of the Turkish Consumers Acceptance of Internet Banking Services. International Journal of Bank Marketing, 19(4), 156-165.

Rogers, E. M. (1995). Diffusion of innovations ( $4^{\text {th }}$ ed.). The Free Press: New York.

Rogers, E. M. (2003). Diffusion of innovations $\left(5^{\text {Th }}\right.$ ed.). The Free Press: New York.

Shih, Y.-Y., \& Fang, K. (2004). The use of a decomposed theory of planned behavior to study Internet banking in Taiwan. Internet Research, 14(3), 213-223.

Siyanbola, T. (2013). The effect of cashlite banking on Nigerian Economy. Canadian Journal of Accounting and Finance, 1(2), 9-19).

Sohail, S, \& Shanmugham, B (2003). E-banking and customer preferences in Malaysia: An empirical investigation. Journal of banking, 3(4), 150-162

Stavins, J. (2001). Effect of consumer characteristics on the use of payment instrument. New England Economics Review, 3, 19-31.

Tan, M., \& Teo, T. (2000). Factors influencing the adoption of Internet banking. Journal of the Association for Information Sciences, 1, 1-42.

Taylor; S., \& Todd, P. (1995). Assessing IT Usage: The Role of Prior Experience. MIS Quarterly, 19 (4)561-570.

Tuj Johara, F. (2014). Consumer's Pattern and Behavior toward the Usage of Mobile Banking. International Journal of Academic Research in Business and Social Sciences, 4(8), 166-181

Tunji, T.S. (2013). The effect of cashlite banking on the Nigerian economy. E-Canadian. Journal of Accounting and Finance, 1(2), 9-19.

Vaidya, S.R. (2011). Emerging Trends on Functional Utilization of Mobile Banking in Developed Markets in Next 3-4 Years. International Review of Business Research Papers, 7(1), $301-312$.

Williamson, D. (2006). Enhanced authentication in Online Banking. Journal of Economic Crime Management, $4(2), 42-51$. 